\title{
Importance of dose-schedule of 5-aza-2'-deoxycytidine for epigenetic therapy of cancer
}

\author{
Maryse Lemaire ${ }^{1}$, Guy G Chabot ${ }^{2}$, Noël JM Raynal ${ }^{1}$, Louise F Momparler ${ }^{1}$, \\ Annie Hurtubise ${ }^{1}$, Mark L Bernstein ${ }^{3}$ and Richard L Momparler*1
}

\begin{abstract}
Address: ${ }^{1}$ Département de pharmacologie, Université de Montréal, Centre de recherche pédiatrique, Service d'Hématologie-Oncologie, Hôpital Sainte-Justine, 3175 Côte Sainte-Catherine, Montréal, Québec H3T 1C5, Canada, ${ }^{2}$ INSERM U640-CNRS UMR8151, Laboratoire de pharmacologie chimique et génétique, Faculté de Pharmacie, Université Paris V, F75006 Paris, France and ${ }^{3}$ Hematology-Oncology, IWK Health center, $5850 / 5980$ University Avenue, Halifax, Nova Scotia, B3K 6R8, Canada

Email: Maryse Lemaire - maryse_lemaire@yahoo.fr; Guy G Chabot - guy.chabot@univ-paris5.fr; Noël JM Raynal - noel.raynal@iaf.inrs.ca; Louise F Momparler - louise.f.momparler@umontreal.ca; Annie Hurtubise - anniehurtubise@yahoo.ca;

Mark L Bernstein - mark.bernstein@iwk.nshealth.ca; Richard L Momparler* - richard.l.momparler@umontreal.ca

* Corresponding author
\end{abstract}

Published: 2 May 2008

BMC Cancer 2008, 8: 128 doi:10.1 |86/147|-2407-8-128
Received: I November 2007

Accepted: 2 May 2008

This article is available from: http://www.biomedcentral.com/I47I-2407/8/I28

(c) 2008 Lemaire et al; licensee BioMed Central Ltd.

This is an Open Access article distributed under the terms of the Creative Commons Attribution License (http://creativecommons.org/licenses/by/2.0), which permits unrestricted use, distribution, and reproduction in any medium, provided the original work is properly cited.

\begin{abstract}
Background: The inactivation of tumor suppressor genes (TSGs) by aberrant DNA methylation plays an important role in the development of malignancy. Since this epigenetic change is reversible, it is a potential target for chemotherapeutic intervention using an inhibitor of DNA methylation, such as 5-aza-2'deoxycytidine (DAC). Although clinical studies show that DAC has activity against hematological malignancies, the optimal dose-schedule of this epigenetic agent still needs to be established.

Methods: Clonogenic assays were performed on leukemic and tumor cell lines to evaluate the in vitro antineoplastic activity of DAC. The reactivation of TSGs and inhibition of DNA methylation by DAC were investigated by reverse transcriptase-PCR and Line-I assays. The in vivo antineoplastic activity of DAC administered as an i.v. infusion was evaluated in mice with murine LI 210 leukemia by measurement of survival time, and in mice bearing murine EMT6 mammary tumor by excision of tumor after chemotherapy for an in vitro clonogenic assay.

Results: Increasing the DAC concentration and duration of exposure produced a greater loss of clonogenicity for both human leukemic and tumor cell lines. The reactivation of the TSGs ( $p 57$ KIP2 in HL60 leukemic cells and p/6CDKN2A in Calu-6 lung carcinoma cells) and the inhibition of global DNA methylation in HL-60 leukemic cells increased with DAC concentration. In mice with LI 210 leukemia and in mice bearing EMT6 tumors, the antineoplastic action of DAC also increased with the dose. The plasma level of DAC that produced a very potent antineoplastic effect in mice with leukemia or solid tumors was $>200 \mathrm{ng} / \mathrm{ml}(>$ I $\mu \mathrm{M})$.

Conclusion: We have shown that intensification of the DAC dose markedly increased its antineoplastic activity in mouse models of cancer. Our data also show that there is a good correlation between the concentrations of DAC that reduce in vitro clonogenicity, reactivate TSGs and inhibit DNA methylation. These results suggest that the antineoplastic action of DAC is related to its epigenetic action. Our observations provide a strong rationale to perform clinical trials using dose intensification of DAC to maximize the chemotherapeutic potential of this epigenetic agent in patients with cancer.
\end{abstract}




\section{Background}

The inactivation of tumor suppressor genes (TSGs) by epigenetic events, such as aberrant DNA methylation, plays an important role in oncogenesis [1,2]. Since epigenetic changes are reversible, they are promising targets for chemotherapy using agents that inhibit DNA methylation [3,4]. 5-Aza-2'-deoxycytidine (decitabine, dacogen, DAC) is a potent demethylating agent [5], that has been shown to reactivate TSGs [3] silenced by promoter DNA methylation $[1,2]$. In preclinical studies DAC was shown to have potent antileukemic activity in the mouse model [6-8]. In addition DAC showed potent antitumor activity against a human tumor xenograft [9]. Its mechanism of action is related to the induction of terminal differentiation, senescence or apoptosis, resulting in an irreversible loss of proliferative potential [10-12].

Clinical trials in patients with hematological malignancies have shown that both low and intermediate doses of DAC can produce responses [13-18]. In patients with solid tumors, low dose DAC produced low response rates [19-21], whereas in a pilot study high doses showed promising activity [22]. Indeed, the dose-schedules of DAC used in the clinical studies were very different, and it appears that the optimal dose still needs to be refined in order to fully exploit its chemotherapeutic potential.

In order to clarify the dose-schedule of DAC as a guide to clinical trials, we have evaluated the antineoplastic activity of DAC both in vitro and in animal models. We have observed that DAC reduced the in vitro clonogenic potential in a dose-dependent manner of both human and murine leukemia and tumor cell lines. The in vitro antineoplastic action of DAC correlated well with its inhibition of DNA methylation and reactivation of TSG in human neoplastic cells. We also observed a correlation between in vitro and in vivo concentrations needed to produce optimal responses in mice with L1210 leukemia or with EMT6 tumor. These observations may be useful in the design of optimized dose-schedules of DAC for future clinical trials aimed at evaluating its full chemotherapeutic potential in patients with cancer.

\section{Methods \\ Chemicals}

DAC (molecular weight 228.2) was obtained from A. Piskala, Institut of Organic Chemistry and Biochemistry, Czechoslovak Academy of Science, Prague, Czeckoslovakia. DAC was dissolved in sterile phosphate buffer saline $\mathrm{pH} 6.8$ (PBS) solution and stored at $-70^{\circ} \mathrm{C}$ to prevent decomposition.

\section{Cell culture}

The mouse lymphoid leukemia cell line L1210 was obtained from Dr. T. Khwaja (University of Southern California, Los Angeles). These cells were maintained in RPMI-1640 medium (Canadian Life Technologies, Burlington, Ontario) with 5\% heat-inactivated fetal calf serum (WISENT, St-Bruno, Quebec) and with $6 \mu \mathrm{M}$ of 2-mercaptoethanol. The mouse mammary tumor cell line EMT6 was obtained from spontaneous mammary tumor of BALB/c mouse [23]. These cells were maintained in MEM F-14 medium (Canadian Life Technologies) with 10\% heat-inactivated fetal calf serum and with 25 units $/ \mathrm{ml}$ of penicillin, $25 \mu \mathrm{g} / \mathrm{ml}$ of streptomycin and $0.1 \mathrm{mg} / \mathrm{ml} \mathrm{of}$ calcium chloride. The doubling time of both murine cell lines was $\sim 12 \mathrm{~h}$. The human acute promyelocytic leukemic cells HL-60 (ATCC, USA) and the lung carcinoma cells Calu-6 were maintained in RPMI-1640 medium (Canadian Life Thecnologies) with 10\% heat-inactivated foetal calf serum (WISENT). The doubling times of the HL-60 and Calu- 6 cells were 16 and 30 h, respectively. All cells lines were maintained at $37^{\circ} \mathrm{C}$ with $5 \% \mathrm{CO}_{2}$.

\section{Clonogenic assays}

A $5 \mathrm{ml}$ aliquot of HL-60 or L1210 (104 cells/ml) in log growth phase were placed in $25 \mathrm{~cm}^{2}$ tissue-culture flasks. The indicated concentrations of DAC were added. The flasks were incubated at $37^{\circ} \mathrm{C}$ and at the indicated times, an aliquot was removed for counting with a Model $\mathrm{Z}$ Coulter Counter. An aliquot of 100 cells was placed in 2 $\mathrm{ml}$ of $0.3 \%$ soft agar RPMI 1640 medium containing 20\% serum for HL-60 (Table 1) or 10\% serum plus $6 \mu \mathrm{M} 2$ mercaptoethanol (Sigma) for L1210 cells (Table 3). For EMT6 tumor, $5 \mathrm{ml}$ (200 cells) were placed in a Petri dish

Table I: Effect of different concentrations and exposure times of DAC on loss of clonogenicity of human HL-60 myeloid leukemic cells.

\begin{tabular}{|c|c|c|c|c|}
\hline \multirow{3}{*}{ DAC Concentration ng/ml $(\mu \mathrm{M})$} & \multicolumn{4}{|c|}{ Loss of clonogenicity (\%) } \\
\hline & \multicolumn{4}{|c|}{ Exposure time } \\
\hline & $2 \mathrm{~h}$ & $6 \mathrm{~h}$ & $24 \mathrm{~h}$ & $48 \mathrm{~h}$ \\
\hline $10(0.044)$ & $11.8 \pm 9.8^{a}$ & $43.9 \pm 10.2^{\mathrm{a}}$ & $44.9 \pm 15.9 \mathrm{a}$ & $69.0 \pm 19.9 a$ \\
\hline $20(0.088)$ & ND & ND & $56.1 \pm 19.2$ & ND \\
\hline $100(0.44)$ & $43.9 \pm 7.8$ & $74.0 \pm 9.8$ & $83.9 \pm 4.9$ & $99.7 \pm 0.8$ \\
\hline $200(0.88)$ & $56.4 \pm 14.8$ & $77.2 \pm 10.7$ & $99.2 \pm 2.1$ & 100 \\
\hline $1,000(4.4)$ & $61.3 \pm 14.7$ & $89.3 \pm 3.8$ & ND & 100 \\
\hline
\end{tabular}

aMean values \pm S.D., $n \geq 4$ 
Table 2: Effect of different concentrations and exposure times of DAC on loss of clonogenicity of human Calu-6 lung carcinoma cells.

\begin{tabular}{|c|c|c|c|c|}
\hline \multirow{2}{*}{ DAC Concentration ng/ml $(\mu \mathrm{M})$} & \multicolumn{4}{|c|}{$\frac{\text { Loss of clonogenicity }(\%)}{\text { Exposure time }}$} \\
\hline & $4 \mathrm{~h}$ & $8 \mathrm{~h}$ & $24 \mathrm{~h}$ & $48 \mathrm{~h}$ \\
\hline $\mathrm{I}(0.0044)$ & ND & ND & $16.4 \pm 9.1^{a}$ & $10.3 \pm 5.9 \mathrm{a}$ \\
\hline $10(0.044)$ & $25.5 \pm 15.6^{\mathrm{a}}$ & $20.1 \pm 15.2^{\mathrm{a}}$ & $30.7 \pm 11.4$ & $22.5 \pm 19.4$ \\
\hline $100(0.44)$ & $59.8 \pm 20.2$ & $71.1 \pm 9.3$ & $83.9 \pm 14.2$ & $71.6 \pm 11.1$ \\
\hline $1,000(4.4)$ & $82.4 \pm 10.2$ & $83.4 \pm 1.1$ & $98.0 \pm 4.2$ & $100 \pm 0$ \\
\hline
\end{tabular}

aMean values \pm S.D., $\mathrm{n} \geq 3$

and incubated for $4 \mathrm{~h}$. Different concentrations of DAC were then added for $18 \mathrm{~h}$ exposure (Table 3 ). The drug was removed and the cells were placed in drug-free medium. For Calu-6 lung carcinoma cells, $2 \mathrm{ml}$ (100 cells) were plated in 6-well dishes and incubated for $24 \mathrm{~h}$ prior to addition of different concentrations of DAC (Table 2). The drug was removed after the different exposure times and the cells were placed in drug-free medium. The number of colonies ( $>500$ cells) was counted after 7 days of incubation for both L1210 and EMT6 cells (Table 3), and after 14 days of incubation for HL-60 (Table 1) and Calu- 6 cells (Table 2). The cloning efficiency of all the cells was in the range of $60-75 \%$.

\section{Isolation of RNA and RT-PCR}

In order to study the epigenetic effect of DAC, the reactivation of the tumor suppressor genes p57CDKN1C (p57) (GenBank accession number NM 000076) [8] on HL-60 cells and p16CDKN2A (p16) (GenBank accession number NM 058197) [24] on Calu- 6 cells was evaluated. HL-60 leukemic cells and Calu-6 lung carcinoma cells were treated with different concentrations of DAC for 48 $\mathrm{h}$ (Fig. 1). Total RNA was isolated $24 \mathrm{~h}$ after drug removal using RNeasy Mini Kit (Qiagen, Mississauga, Ontario, CA). For cDNA synthesis, RNA was reverse-transcribed as previously described [8]. PCR amplifications were performed using HotStar Taq Polymerase (Qiagen) and specific primers spanning different exons for human $18 \mathrm{~S}$ ribosomal RNA (18S) (Gen Bank accession number X03205) [8], p57 [8] and p16 [25]. The $18 \mathrm{~S}$ was amplified as an internal control. Samples were amplified in a Whatman Biometra T gradient thermocycler (Göttingen, Germany) under the following conditions (previously described for $18 \mathrm{~S}$ and p57 [8]). For p16, $15 \mathrm{~min}$ at $95^{\circ} \mathrm{C}$ to activate Taq polymerase, denaturation at $94^{\circ} \mathrm{C}$ for $45 \mathrm{~s}$, annealing at $59^{\circ} \mathrm{C}$ for $30 \mathrm{~s}$ and extension at $72^{\circ} \mathrm{C}$ for 30 $\mathrm{s}$, for 5 cycles. Then, the annealing temperature was lowered by $2{ }^{\circ} \mathrm{C}$ for an additional 35 cycles. The length or the PCR products were 110, 167 and $117 \mathrm{bp}$ for $18 \mathrm{~S}$, p57 and p16 respectively. For each gene, the number of cycles was determined during the exponential phase of DNA amplification. The PCR products were electrophoresed on $2 \%$ agarose gel and detected by ethidium bromide staining. For quantitative detection of gene expression, we used the $18 \mathrm{~S}$ as the reference standard to normalize the data. The concentration of the amplified DNA was determined by Agilent 2100 Bioanalyzer (Palo Alto, CA). This instrument uses a very sensitive capillary electrophoresis and fluorescent detection to measure the concentration and size of DNA from a sample size of only $1 \mu \mathrm{l}$ (Fig. $1 \mathrm{~B}$ and $1 \mathrm{C}$ ).

\section{Isolation of DNA and bisulfite treatment}

In order to study the global methylation status of the genome of the HL-60 leukemic cells, the LINE-1 (GenBank accession number AF148856) assay was used [26]. The specific methylation status of the promoter of the $\mathrm{p} 57$ gene (GenBank accession number NC 000011) has also been studied in these cells. HL-60 cells were treated with different concentrations of DAC $(10,100$ and $1000 \mathrm{ng} / \mathrm{ml}$ or $0.044,0.44$ and $4.4 \mu \mathrm{M}$ ) for $48 \mathrm{~h}$. Genomic DNA was

Table 3: Effect of different concentrations of DAC on loss of clonogenicity by LI 2 I 0 murine lymphoblastic leukemia, or by EMT6 murine mammary tumor cells ${ }^{a}$

\begin{tabular}{ccc}
\hline DAC Concentration $\mathrm{ng} / \mathrm{ml}(\mu \mathrm{M})$ & LI210 Loss of clonogenicity $(\%)$ & EMT6 Loss of clonogenicity $(\%)$ \\
\hline $1(0.0044)$ & $25.3 \pm 12.4 \mathrm{~b}$ & - \\
$10(0,044)$ & $41.4 \pm 8.8$ & $12.3 \pm 5.5^{\mathrm{b}}$ \\
$100(0.44)$ & $98.6 \pm 1.3$ & $69.3 \pm 10.3$ \\
$1,000(4.4)$ & 100 & $75.0 \pm 10.8$ \\
$10,000(44)$ & - & $99.2 \pm 0.3$
\end{tabular}

a $18 \mathrm{~h}$ exposure to DAC.

bMean values \pm S.D., $n \geq 3$. 
A

$48 \mathrm{~h}$ exposure

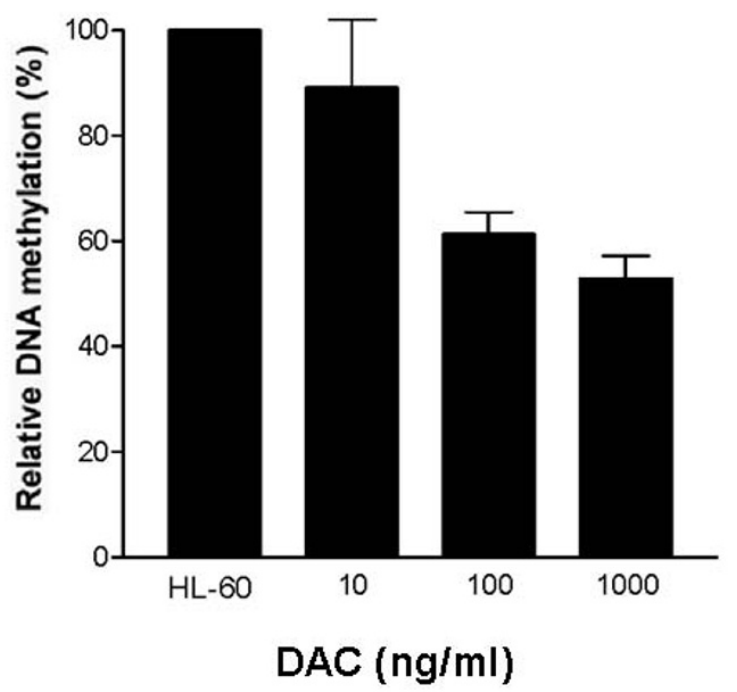

C

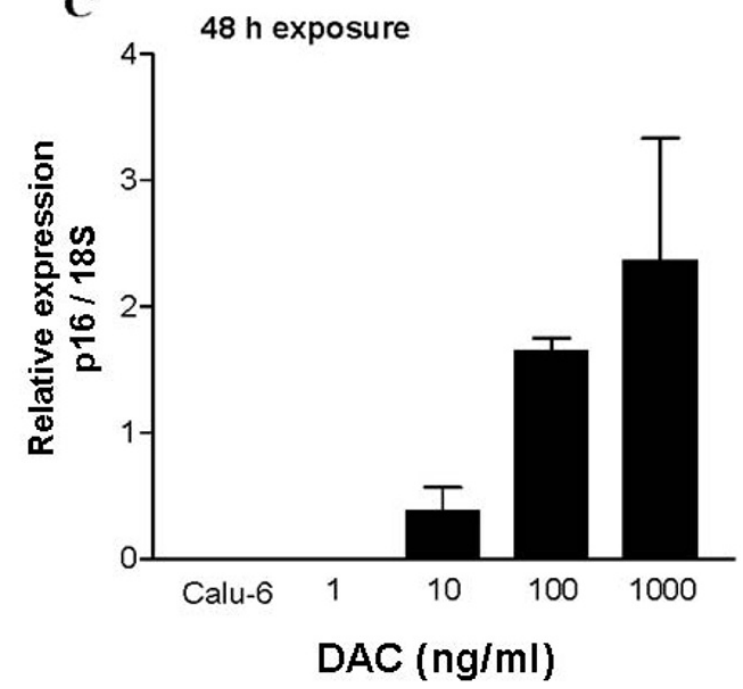

B

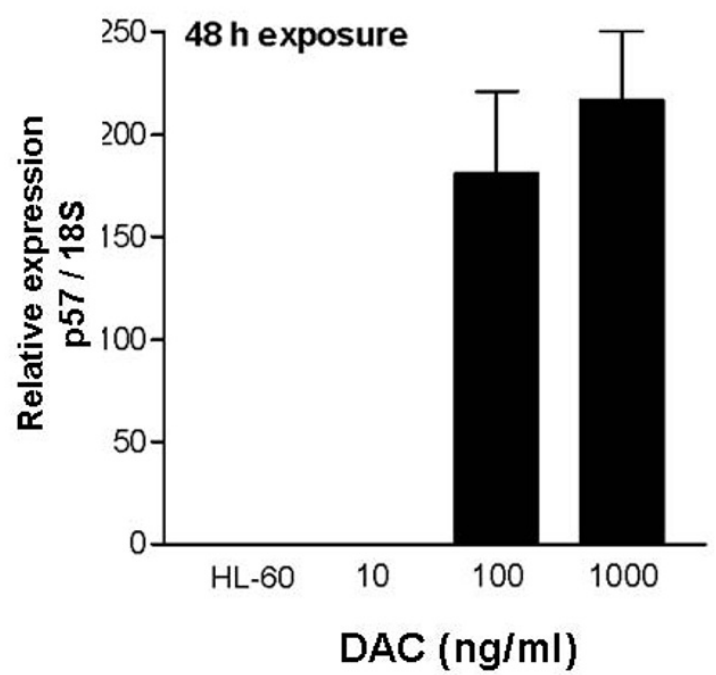

Figure I

Effect of DAC concentration on DNA methylation and reactivation of p57 and p / 6 tumor suppressor genes. A), HL-60 cells were treated with the indicated concentrations of DAC for $48 \mathrm{~h}$. Total DNA was isolated at $72 \mathrm{~h}$ and the LINE-I element gene methylation status was analyzed by COBRA assay. B), HL-60 cells were treated with the indicated concentrations of DAC for $48 \mathrm{~h}$ and total RNA was isolated at $72 \mathrm{~h}$. Gene expression of $18 \mathrm{~S}$ ribosomal RNA gene and $\mathrm{p} 57$ were analyzed by RT-PCR. The amount of DNA amplified during the exponential phase of PCR was analyzed by quantification of amplified DNA by an Agilent 2100 Bioanalyzer. The control cells are HL-60 with no drug treatment. Control vs DAC $100 \mathrm{ng} /$ $\mathrm{ml}$ or $\mathrm{I}, 000 \mathrm{ng} / \mathrm{ml} \mathrm{p}<0.00 \mathrm{I}$. C), Calu- 6 cells were treated with the indicated concentrations of DAC for $48 \mathrm{~h}$. Total RNA was isolated at $72 \mathrm{~h}$ and $18 \mathrm{~S}$ ribosomal RNA gene and pl6 gene expression analyzed by RT-PCR. The amount of DNA amplified during the exponential phase of PCR was analyzed by quantification of amplified DNA by an Agilent 2100 Bioanalyzer. For the quantitative detection of gene expression, we used $18 \mathrm{~S}$ as the reference to normalize the data. The control cells were Calu- 6 with no drug treatment. Control vs DAC $100 \mathrm{ng} / \mathrm{ml} \mathrm{p}<0.01$. Data are mean values \pm S.D., $\mathrm{n} \geq 3$. 
isolated $24 \mathrm{~h}$ after drug removal using DNeasy Tissue Kit (Qiagen). Genomic DNA was then treated with bisulfite [8]. This bisulfite treatment converts unmethylated cytosine residues to uracil, whereas 5-methylcytosine residues remain unchanged.

\section{Quantitation of DNA methylation by LINE assay}

Analysis of changes in DNA methylation after DAC treatment were evaluated by the method used for the LINE-1 assay [26]. PCR was performed on bisulfite treated DNA using specific primers for either LINE-1 (sense 5'-TTA GGG AGT GTT AGA TAG TGG-3' and antisense 5'-ATA CCC TAC CCC CAA AAA TAA AAC-3' (primer sequences were designed by Allen $\mathrm{S}$. Yang, personal communication). The PCR conditions were the same as RT-PCR for $18 \mathrm{~S}$, except the annealing temperature was $53^{\circ} \mathrm{C}$ and the total number of cycles was 35 . The PCR products were then purified using the DNA Clean and Concentrator Kit (Zymo Research, CA, USA) and digested with Hinf I enzyme (New Englend BioLabs, MA, USA) according to manufacturer's protocols. Hinf I will only cut the repetitive LINE-1 elements that were originally methylated, leading to a 53 and a $398 \mathrm{bp}$ fragmentation product that can be quantified. The samples were placed on a $2 \%$ agarose gel, detected by ethidium bromide staining and their concentrations were evaluated by the Agilent 2100 Bioanalyzer.

\section{Chemotherapy in mice}

$\mathrm{BALB} / \mathrm{C} \times \mathrm{DBA} / 2$ (hereafter called $\mathrm{CD}_{2} \mathrm{~F}_{1}$ ) male mice 24$28 \mathrm{~g}$ were obtained from Taconic Biotechnology (Germantown, NY, USA). The animal committee approved the experimental protocols and the animals were handled in accordance with institutional guidelines. Transplantation of L1210 leukemic cells was performed by weekly i.p. injections of $10^{4}$ cells in $0.1 \mathrm{ml}$ of RPMI-1640 medium into $\mathrm{CD}_{2} \mathrm{~F}_{1}$ mice. Seven days later, the ascitic fluid was obtained and a cell count of the leukemic cells was performed with a hemocytometer. For chemotherapy of leukemia, the mice were injected i.v. with $0.1 \mathrm{ml}$ of L1210 $\left(10^{4}\right.$ cells) [6]. DAC was dissolved in PBS and sterilized by $0.2 \mu \mathrm{m}$ filtration (Fig. 2). For i.v. infusion administration, a Harvard infusion pump was used at a flow rate of 0.22 $\mathrm{ml} / \mathrm{h}$ via a 25-gauge needle attached to a winged infusion set into the lateral tail vein. Mice were placed in a restrainer cage during drug treatment [8]. The survival time of each group of leukemic mice was monitored and the increase in life span (ILS) calculated (Fig. 2). Mice that survived $>60$ days after drug treatment were classified as long-term survivors.

\section{In vitro clonogenic assay of tumors after in vivo chemotherapy [27]}

For the transplantation of EMT6 mammary tumor, the tumor was removed by surgery and cut into small pieces

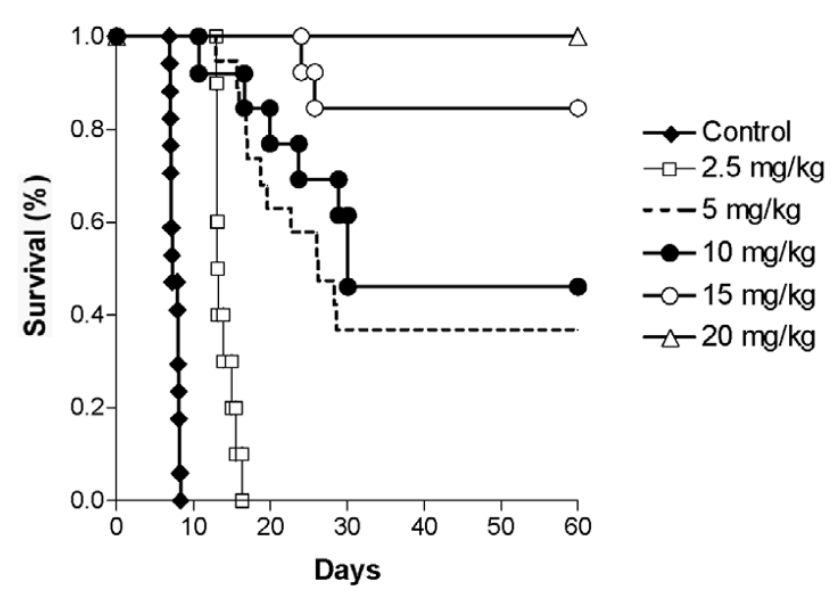

Figure 2

Effect of DAC on the survival time of mice with

LI 2 I 0 lymphoid leukemia. CD2F, mice received I $\times 10^{4}$ LI 2 I 0 leukemic cells on day I. Chemotherapy was started on day 2 with the indicated doses of DAC for $18 \mathrm{~h}$ i.v. infusion. The survival time of mouse was monitored. Control: $\mathrm{n}=10$; DAC $2.5 \mathrm{mg} / \mathrm{kg}: \mathrm{n}=10$; DAC $5 \mathrm{mg} / \mathrm{kg}: \mathrm{n}=19 ; \mathrm{DAC} 10$ $\mathrm{mg} / \mathrm{kg}: \mathrm{n}=\mathrm{I} 3 ; \mathrm{DAC} 15 \mathrm{mg} / \mathrm{kg}: \mathrm{n}=12 ;$ DAC $20 \mathrm{mg} / \mathrm{kg}: \mathrm{n}=$ 3.

under sterile conditions. A tumor fragment of $\sim 1 \mathrm{~mm}$ diameter was injected s.c. Transplantations were performed every two weeks. CD2 $\mathrm{F}_{1}$ mice with EMT6 tumors received DAC when the tumors reached a weight of $\sim 200$ mg ( $14 \pm 2$ days after s.c. injection of EMT6 cells). Mice were administered the i.v. infusion of DAC at a flow rate of $0.25 \mathrm{ml} / \mathrm{h}$ at $1.67 \mathrm{mg} / \mathrm{kg} / \mathrm{h}$ for different infusion times or a single $18 \mathrm{~h}$ i.v. infusion at different doses. Tumors were then removed, cut and washed with medium. Cells were trypsinized and filtered (37 $\mu \mathrm{m})$ to remove tumor fragments. The single cell suspension was centrifuged, washed with medium and counted. Cells were then plated in Petri dishes at a density of 500 and 1000 cells/dish and 14 days later, colonies were fixed, stained with Giemsa and counted. The cloning efficiency was $\sim 10 \%$.

\section{Pharmacokinetic analysis}

Mice received DAC by i.v. infusion for $4 \mathrm{~h}$ to reach a steady state concentration at the indicated rate of infusion corresponding to different doses levels (Table 4). The mice were anesthetized with carbon dioxide. At 1-2 min post-infusion, blood samples were obtained by cardiac puncture using a syringe flushed with heparin. The blood samples were placed on ice and centrifuged at 10,000 $\times \mathrm{g}$ for $5 \mathrm{~min}$. The supernatant was obtained and used for bioassay as described previously [22]. The bioassay measures the growth inhibition of L1210 leukemic cells after $48 \mathrm{~h}$ 
Table 4: Pharmacokinetics of DAC in mice.

\begin{tabular}{ccc}
\hline Total dose $^{\mathrm{a}}(\mathrm{mg} / \mathrm{kg})$ & Rate infusion $(\mathrm{mg} / \mathrm{kg} / \mathrm{h})$ & Plasma level $\mathrm{ng} / \mathrm{ml}(\mu \mathrm{M})$ \\
\hline 5 & 0.278 & $80 \pm 0.3^{\mathrm{b}}(0.35)$ \\
10 & 0.556 & $190 \pm 0.5(0.83)$ \\
20 & 1.11 & $610 \pm 0.9(2.68)$
\end{tabular}

a $18 \mathrm{~h}$ i.v. infusion of DAC. Blood sample was obtained at $4 \mathrm{~h}$.

bMean values \pm S.D., $\mathrm{n} \geq 3$.

incubation. Different dilutions of the plasma were added to the medium and the growth inhibition determined. The plasma concentration of DAC was estimated from the standard curve (not shown) with known concentrations of this analog. The experiment was repeated twice and performed in duplicates.

\section{Statistical considerations}

For statistical analysis one-way ANOVA was performed. The p-value was evaluated accordingly to Tukey's method [28]. A value $\mathrm{p}<0.05$ was taken to indicate statistical significance. The data represented the mean values \pm S.D. for $\mathrm{n} \geq 3$.

\section{Results}

Clonogenic assays were performed on human leukemic and tumor cell lines to facilitate the translation of in vitro data to the design of a protocol for a clinical trial. Human HL-60 myeloid leukemic cells were exposed to different concentrations of DAC for different exposure times (Table 1). DAC produced a loss of clonogenicity in a time- and a dose-dependent manner. For a $24 \mathrm{~h}$ exposure, the concentration that produced $50 \%$ loss of clonogenicity (IC50) value was between 10 and $20 \mathrm{ng} / \mathrm{ml}(0.044$ and 0.088 $\mu \mathrm{M})$, whereas $200 \mathrm{ng} / \mathrm{ml}(0.88 \mu \mathrm{M})$ produced almost $100 \%$ in loss of clonogenicity.

Similarly, Calu-6 lung carcinoma cells were exposed to different concentrations of DAC for different exposure times (Table 2). DAC produced a loss of clonogenicity in a dose- and a time-dependent manner. For the 4 and $8 \mathrm{~h}$ exposure times, the IC50 value was in the range of $100 \mathrm{ng} /$ $\mathrm{ml}(0.44 \mu \mathrm{M})$. Compared to HL-60 leukemic cells, higher concentrations and longer exposure times were required to achieve a loss of clonogenicity of approximately $>90 \%$.

In order to fully understand the antineoplastic activity of DAC, we evaluated its epigenetic action at different concentrations on human leukemic and tumor cell lines. The global DNA methylation status of HL-60 leukemic cells was monitored by tracking the amount of methylated LINE-1 element [26] (Fig. 1A). After a $48 \mathrm{~h}$ exposure, 100 $\mathrm{ng} / \mathrm{ml}(0.44 \mu \mathrm{M})$ of DAC reduced the global methylation status of HL-60 by $40 \%$ ( $p<0.001$, compared to untreated cells), which seems to be sufficient to inhibit almost
$100 \%$ of the clonogenic potential (Table 1 ). Lower concentration of DAC $(10 \mathrm{ng} / \mathrm{ml} ; 0.044 \mu \mathrm{M})$ did not produce a significant loss in global DNA methylation ( $\mathrm{p}>0.05$, compared to untreated cells) in HL-60 cells. Similar results were obtained from the examination of the tumor suppressor gene p57, reported to be methylated in HL-60 cell lines [8]. HL-60 cells exposed to $100 \mathrm{ng} / \mathrm{ml}(0.44 \mu \mathrm{M})$ for $48 \mathrm{~h}$ showed re-expression of p57 mRNA (Fig. 1B). These data correlate well with the concentration required to significantly decrease the promoter methylation of p57 as determined by the methylation-specific PCR assay [8] (data not shown). When HL-60 cells are exposed to lower concentrations of DAC $(10 \mathrm{ng} / \mathrm{ml} ; 0.044 \mu \mathrm{M})$, DNA hypomethylation was not detected, even though that concentration could inhibit approximately $70 \%$ of the clonogenicity of these cells (Table 1 ).

We next investigated the re-expression of p16 mRNA on Calu-6 lung carcinoma cells exposed to different concentrations of DAC (Fig. 1C), because p16 has been reported to be completely repressed by DNA methylation in these cells [24]. The observed re-expression of p 16 was found to be time- and dose-dependent, with $100 \mathrm{ng} / \mathrm{ml}(0.44 \mu \mathrm{M})$ required to achieve a significant re-expression at $24 \mathrm{~h}$ (data not shown) and 48 h (Fig. 1C). These data correlated well with the efficacy in reducing the clonogenic potential of DAC, since both exposure times gave $\sim 80 \%$ loss of clonogenicity (Table 2).

The loss of clonogenicity was determined by the reduction in colony formation after an $18 \mathrm{~h}$ drug exposure of the L1210 murine lymphoid leukemic cells and of the EMT6 mammary tumor cells to different concentrations of DAC (Table 3). The IC50 was $\sim 15 \mathrm{ng} / \mathrm{ml}(0.066 \mu \mathrm{M})$ for L1210 and $\sim 50 \mathrm{ng} / \mathrm{ml}(0.22 \mu \mathrm{M})$ for EMT6, according to calculations. In a previous study on L1210, we also observed that shorter exposure times to DAC were less effective indicating a time-dependence $[6,8]$. DAC produced a loss of clonogenicity in a dose-dependent manner in both cell lines, although L1210 leukemic cells are much more sensitive than the EMT6 cells. It is noteworthy that both murine and human leukemic cells were more sensitive to the antineoplastic action of 5-AZA-CdR than the solid tumor cells of either species. 
$\mathrm{CD}_{2} \mathrm{~F}_{1}$ mice received an i.v. injection of $10^{4} \mathrm{~L} 1210$ leukemic cells on day 1 and chemotherapy was started on day 2. The short plasma half-life of DAC in mice of 20-30 min [29] supports the use of a continuous i.v. infusion for drug administration. We administered different doses of DAC ranging from 2.5 to $20 \mathrm{mg} / \mathrm{kg}$ (Fig. 2). The total dose of $2.5 \mathrm{mg} / \mathrm{kg}$ increased the survival time to $13.9 \pm 1.3$ days, an $85 \%$ increase in life span as compared to untreated mice which had a survival time of $7.5 \pm 0.5$ days. Doubling the dose to $5 \mathrm{mg} / \mathrm{kg}$ produced an increase in survival time to 26 days with $30 \%$ of the mice surviving more than 60 days, designated as long-term survivors in this model. Increasing the dose of DAC to 10 and $15 \mathrm{mg} / \mathrm{kg}$ produced a further increase in survival time and long-term survivors. At a total dose of $20 \mathrm{mg} / \mathrm{kg}$ of DAC, $100 \%$ of treated mice survived more than 60 days, indicating that they were all long-term survivors as described in this model (Fig. 2). The toxicity produced by the $20 \mathrm{mg} / \mathrm{kg}$ dose of DAC was minimal as indicated by the $<3 \%$ loss in body weight (data not presented).

A very sensitive method to evaluate the antitumor activity of DAC is to determine the cloning efficiency of tumor cells in vitro after an in vivo treatment. This model is more sensitive than measuring tumor volume because it is possible to detect 2 to 4 log cell kill. Mice were injected with EMT6 mammary tumor cells s.c. and the treatment with DAC was started when tumor reached a weight of approximately $200 \mathrm{mg}$. In the initial experiments, the mice received a constant rate of infusion of DAC $(1.67 \mathrm{mg} / \mathrm{kg} /$ h) for different infusion times (Fig. 3A). The tumors were removed $48 \mathrm{~h}$ after treatment, the cells plated and colonies were counted 14 days later. The loss of clonogenicity of the tumor cells increased with the duration of the DAC infusion. A complete loss of clonogenicity was observed for the $24 \mathrm{~h}$ infusion at a total dose of $40 \mathrm{mg} / \mathrm{kg}$ of DAC. However, this latter dose-schedule was very toxic to the mice. In the second set of experiments, the mice received a constant $18 \mathrm{~h}$ infusion of DAC at different total doses of 7.5, 15, 30 and $60 \mathrm{mg} / \mathrm{kg}$ (Fig. 3B). A reduction in the survival fraction of the tumor cells was dependent on the dose of this analogue. DAC at a total dose of $30 \mathrm{mg} / \mathrm{kg}$ produced an estimated $\sim 2 \log$ cell kill of the tumor cells (Fig. 3B).

In a standard pharmacokinetic analysis, about 4 plasma half-lives are required for a drug to reach steady state level during a continuous i.v. infusion. The elimination half-
A

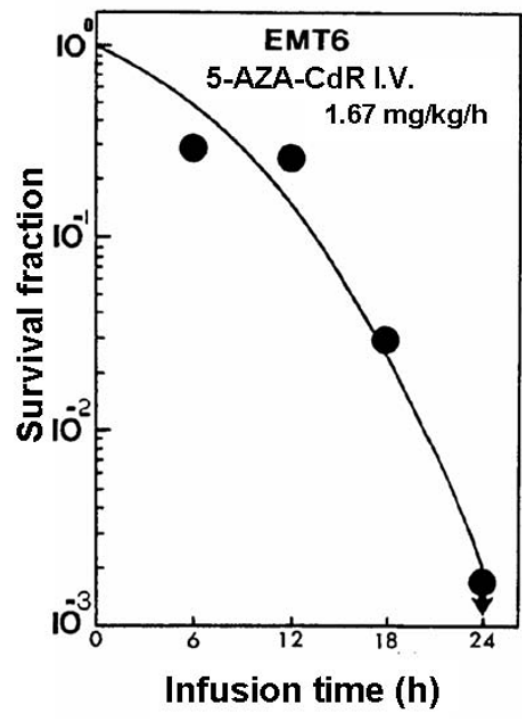

B

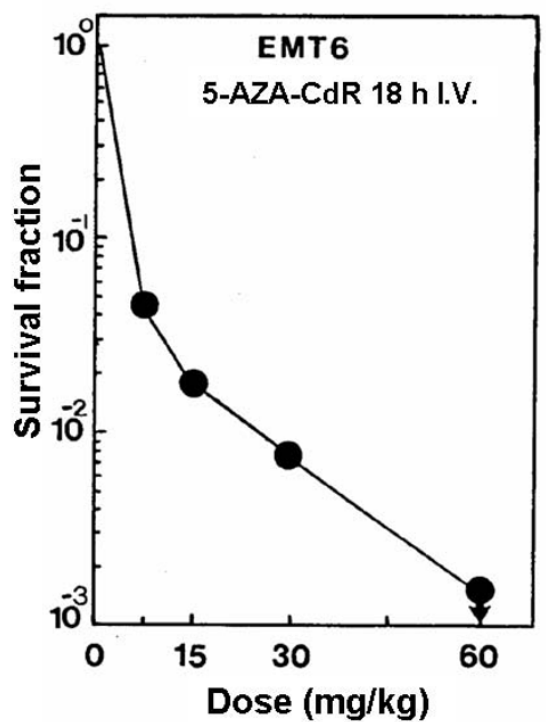

\section{Figure 3}

Effect of DAC therapy on mice on the survival of EMT6 mammary tumor cells. A), Mice received an i.v. infusion of DAC at $1.67 \mathrm{mg} / \mathrm{kg} / \mathrm{h}$ for different duration $(6,12,18$ or $24 \mathrm{~h})$ for total doses of $10,20,30$ or $40 \mathrm{mg} / \mathrm{kg}$, respectively. B), Mice received an $18 \mathrm{~h}$ i.v. infusion at different doses of DAC $(7.5,15,30$ or $60 \mathrm{mg} / \mathrm{kg})$. CD2F, mice were injected s.c. with EMT6 tumor cells on day I. DAC treatment as indicated was administered 14 days later. At $48 \mathrm{~h}$ post-treatment the tumors were removed and cells were plated in dishes for colony formation analysis. Each data point: $\mathrm{n}=2$. The cloning efficiency was about $10 \%$. 
life of DAC in plasma of mice was estimated to be 29 min [29]. For DAC it takes about $2 \mathrm{~h}$ to reach steady state level. In order to determine plasma level of DAC in our leukemic mouse model that produced 100\% long-term survivors, we obtained blood samples after $4 \mathrm{~h}$ infusion time and estimated the level of this analogue using a bioassay. When DAC was infused at a rate of $1.11 \mathrm{mg} / \mathrm{kg} / \mathrm{h}$, which corresponds to the total dose of $20 \mathrm{mg} / \mathrm{kg}$ for $18 \mathrm{~h}$ infusion, its estimated plasma level was $610 \mathrm{ng} / \mathrm{ml}(2.68 \mu \mathrm{M})$ (Table 4).

\section{Discussion}

The silencing of TSGs by aberrant DNA methylation is a frequent event in leukemogenesis and tumorigenesis. Since this epigenetic event is reversible, it provides a very interesting target for cancer therapy with DAC, a potent and specific inhibitor of DNA methylation. Recently, DAC was approved by the FDA for the treatment of the hematological malignancy, myelodysplastic syndrome $[13,15,17]$. However, even though some information is available concerning the dose-scheduling of DAC, the optimal dosing in humans is still not well defined. The purpose of the present preclinical study was therefore to better define the dose-schedule of DAC in order to provide data that may be useful to clinical investigators in their effort to improve the efficacy of DAC therapy in patients with cancer.

In this preclinical study we have investigated the in vitro and in vivo antineoplastic activity of DAC on leukemic and tumor cells. The objective of our study was to correlate the in vitro concentrations of DAC that produced a significant loss of clonogenicity with the doses that produce a potent in vivo antineoplastic effect in mouse cancer models. Our data clearly show that the in vitro loss of clonogenicity by human and murine leukemic and tumor cells increase with concentration of DAC. For HL-60 leukemic cells and Calu-6 lung carcinoma cells the loss of clonogenicity at the higher concentrations of DAC correlated with its capacity to reactivate TSGs in these cell lines. In addition, the inhibition of DNA methylation by DAC in the HL-60 leukemic cells also correlated with the loss of clonogenicity. This latter result is in accord with our previous study in mice with L1210 leukemia in which the chemotherapeutic action of DAC was correlated with its inhibition of DNA [7]. These observations further support the hypothesis that the antineoplastic action of DAC is related to its epigenetic action.

The antineoplastic action of DAC against both leukemic and tumor cells also increased with the duration of treatment. The longer exposure times allowed a greater fraction of non-S phase cells to progress into $S$ phase, where DAC exerts its antineoplastic action [30]. Due to its $S$ phase specificity, the duration of DAC treatment is a very important parameter that should be taken into consideration in the design of trials with this epigenetic agent in cancer patients.

In mice with L1210 leukemia, the antineoplastic activity of DAC increased markedly with the dose. The estimated steady-state plasma level of DAC was $\sim 185 \mathrm{ng} / \mathrm{ml}(\sim 0.8$ $\mu \mathrm{M}$ ) when administered at a total dose of $10 \mathrm{mg} / \mathrm{kg}$ as a 15-h i.v. infusion. This treatment produced $50 \%$ longterm survivors. The in vitro colony assay on L1210 leukemic cells predicts a $>98 \%$ loss of clonogenicity with this concentration, indicating a good correlation between the in vitro and in vivo antileukemic action of DAC. The question arises: Is it possible to translate the observations of DAC in this mouse model of leukemia to the clinical treatment of patients with leukemia? In this regard, it is interesting to note that our data on cytosine arabinoside (cytarabine, ARA-C) in the L1210 leukemia model in mice [31] shows a good correlation with clinical studies on intensive dose ARA-C in patients with acute myeloid leukemia [32].

Although ARA-C and DAC are both deoxycytidine analogues with identical metabolism and S phase specificity, these agents have different mechanisms of action. One major concern for clinical trials using DAC dose-intensification is its hematopoietic toxicity. However, the hematopoietic toxicity seen with post-remission high dose ARA$\mathrm{C}$ in leukemic patients is reversible [31]. Similarly, it should be possible to investigate more intensive dose therapy with DAC in patients with leukemia who have a good performance status, since the pharmacology would predict reversible toxicity with DAC as well [18].

The antineoplastic action of DAC against the EMT6 tumor in mice also increased markedly with dose. In this model, the tumor was excised after DAC treatment, and the cell suspension obtained for the in vitro clonogenic assay. We selected this model because it quantifies the survival of tumor stem cells, which should be the key target of chemotherapy [33]. DAC at total dose of $15 \mathrm{mg} / \mathrm{kg}$ produced $\sim 2$ log reduction in clonogenic survival of EMT6 tumor cells. The estimated plasma level of DAC during this infusion was $200-400 \mathrm{ng} / \mathrm{ml}(0.88-1.76 \mu \mathrm{M})$. In patients with solid tumors low dose DAC showed only minimal clinical activity $[20,21]$. For example, DAC (60 to $90 \mathrm{mg} / \mathrm{m}^{2}$ total dose) administered as a continuous $72 \mathrm{~h}$ i.v. infusion gave steady state plasma levels in the range of $10 \mathrm{ng} / \mathrm{ml}(0.044$ $\mu \mathrm{M})$ [21]. In our pilot study on patients with advanced lung cancer, we used intensive dose DAC (400 to $660 \mathrm{mg} /$ $\mathrm{m}^{2}$ as $8 \mathrm{~h}$ i.v. infusion) and observed some very promising responses [22]. The mean steady-state DAC plasma level in our study was estimated to be $\sim 650 \mathrm{ng} / \mathrm{ml}(2.85 \mu \mathrm{M})$. These preliminary clinical observations indicate that higher plasma levels of DAC are required to obtain signif- 
icant antitumor activity in patients and are in accord with our preclinical data. In addition, higher plasma levels of DAC also have the potential to overcome the problem of limited penetration of the anticancer drug into the tumor as a possible cause of failure to respond to chemotherapy [34]. The antitumor activity of DAC in patients undoubtely merits further investigation in order to better refine the dose-scheduling of this epigenetic agent in patients.

\section{Conclusion}

The in vitro assays indicate that the antineoplastic action of DAC on leukemic and tumor cells increase markedly with concentration. The in vivo antineoplastic action of DAC against murine leukemia and tumor also increase markedly with the dose. Pharmacokinetic analyses indicate that the plasma concentration of DAC that produce a potent in vivo antineoplastic effect is also very effective in reducing the in vitro clonogenicity of leukemic and tumor cells. These observations provide a strong rationale for dose intensification in future clinical studies in order to fully develop the chemotherapeutic potential of DAC in patients with cancer [35-37]. Once a very effective dose schedule for DAC is established, combination studies with other gene reactivating drugs, such as histone deacetylase inhibitors, are warranted [38-41].

\section{Competing interests}

The authors declare that they have no competing interests.

\section{Authors' contributions}

ML carried out the clonogenic assays, molecular studies, chemotherapy of leukemia in mice and drafted the manuscript. GGC carried chemotherapy of tumors in mice, clonogenic assays, and drafted the manuscript. NJ-MR carried out the pharmacokinetic experiments and drafted the manuscript. LFM carried out the chemotherapy of leukemia in mice. AH performed the clonogenic assays on tumors. MLB evaluated the data and drafted the manuscript. RLM conceived the study, participated in its design and coordination, and helped to draft the manuscript. All authors read and approved the final manuscript.

\section{Acknowledgements}

This study was supported by grants from the Canadian Cancer Society (RLM \& MLB \#0I4|93) and Cancer Research Society (RLM \& MLB). ML is supported by a studentship from the Fonds de la Recherche en Santé du Québec.

\section{References}

I. Jones PA, Laird PW: Cancer epigenetics comes of age. Nat Genet 1999, 21:163-167.

2. Jones PA, Baylin SB: The fundamental role of epigenetic events in cancer. Nat Rev Genet 2002, 3:415-428.

3. Momparler RL, Bovenzi V: DNA methylation and cancer. J Cell Physiol 2000, I 83: I 45-I54.

4. Momparler RL: Epigenetic therapy of cancer with 5-aza-2'deoxycytidine (decitabine). Semin Oncol 2005, 32:443-45I.
5. Momparler RL: Pharmacology of 5-Aza-2'-deoxycytidine (decitabine). Semin Hematol 2005, 42:S9-16.

6. Momparler RL, Gonzales FA: Effect of intravenous infusion of 5aza-2'-deoxycytidine on survival time of mice with LI210 leukemia. Cancer Res 1978, 38:2673-2678.

7. Wilson VL, Jones PA, Momparler RL: Inhibition of DNA methylation in LI210 leukemic cells by 5-aza-2'-deoxycytidine as a possible mechanism of chemotherapeutic action. Cancer Res 1983, 43:3493-3496.

8. Lemaire M, Momparler LF, Bernstein ML, Marquez VE, Momparler RL: Enhancement of antineoplastic action of 5-aza-2'-deoxycytidine by zebularine on LI 210 leukemia. Anticancer Drugs 2005, 16:301-308.

9. Braakhuis BJ, van Dongen GA, van Walsum M, Leyva A, Snow GB: Preclinical antitumor activity of 5-aza-2'-deoxycytidine against human and neck cancer xenografts [corrected]. Invest New Drugs 1988, 6:299-304.

10. Jones PA, Taylor SM: Cellular differentiation, cytidine analogs and DNA methylation. Cell 1980, 20:85-93.

II. Momparler RL, Dore BT, Momparler LF: Effect of 5-aza-2'-deoxycytidine and retinoic acid on differentiation and c-myc expression in HL-60 myeloid leukemic cells. Cancer Lett 1990, 54:2I-28.

12. Pinto A, Attadia V, Fusco A, Ferrara F, Spada OA, Di Fiore PP: 5-Aza2'-deoxycytidine induces terminal differentiation of leukemic blasts from patients with acute myeloid leukemias. Blood 1984, 64:922-929.

13. Issa JP, Garcia-Manero G, Giles FJ, Mannari R, Thomas D, Faderl S, Bayar E, Lyons J, Rosenfeld CS, Cortes J, Kantarjian HM: Phase I study of low-dose prolonged exposure schedules of the hypomethylating agent 5-aza-2'-deoxycytidine (decitabine) in hematopoietic malignancies. Blood 2004, 103:1635-1640.

14. Kantarjian HM, O'Brien S, Cortes J, Giles FJ, Faderl S, Issa JP, GarciaManero G, Rios MB, Shan J, Andreeff M, Keating M, Talpaz M: Results of decitabine (5-aza-2'deoxycytidine) therapy in 130 patients with chronic myelogenous leukemia. Cancer 2003, 98:522-528.

15. Wijermans P, Lubbert M, Verhoef G, Bosly A, Ravoet C, Andre M, Ferrant A: Low-dose 5-aza-2'-deoxycytidine, a DNA hypomethylating agent, for the treatment of high-risk myelodysplastic syndrome: a multicenter phase II study in elderly patients. J Clin Oncol 2000, 18:956-962.

16. Ruter B, Wijermans PW, Lubbert M: Superiority of prolonged low-dose azanucleoside administration? Results of 5-aza-2'deoxycytidine retreatment in high-risk myelodysplasia patients. Cancer 2006, 106:1744-1750.

17. Kantarjian H, Issa JP, Rosenfeld CS, Bennett JM, Albitar M, DiPersio J, Klimek V, Slack J, de Castro C, Ravandi F, Helmer R 3rd, Shen L, Nimer SD, Leavitt R, Raza A, Saba H: Decitabine improves patient outcomes in myelodysplastic syndromes: results of a phase III randomized study. Cancer 2006, 106:1794-I803.

18. Rivard GE, Momparler RL, Demers J, Benoit P, Raymond R, Lin K, Momparler LF: Phase I study on 5-aza-2'-deoxycytidine in children with acute leukemia. Leukemia research 1981, 5:453-462.

19. van Groeningen CJ, Leyva A, O'Brien AM, Gall HE, Pinedo HM: Phase $I$ and pharmacokinetic study of 5-aza-2'-deoxycytidine (NSC 1277/6) in cancer patients. Cancer Res 1986, 46:483।-4836.

20. Samlowski WE, Leachman SA, Wade M, Cassidy P, Porter-Gill P, Busby L, Wheeler R, Boucher K, Fitzpatrick F, Jones DA, Karpf AR: Evaluation of a 7-day continuous intravenous infusion of decitabine: inhibition of promoter-specific and global genomic DNA methylation. J Clin Oncol 2005, 23:3897-3905.

21. Schrump DS, Fischette MR, Nguyen DM, Zhao M, Li X, Kunst TF, Hancox A, Hong JA, Chen GA, Pishchik V, Figg WD, Murgo AJ, Steinberg SM: Phase I study of decitabine-mediated gene expression in patients with cancers involving the lungs, esophagus, or pleura. Clin Cancer Res 2006, I 2:5777-5785.

22. Momparler RL, Bouffard DY, Momparler LF, Dionne J, Belanger K, Ayoub J: Pilot phase I-II study on 5-aza-2'-deoxycytidine (Decitabine) in patients with metastatic lung cancer. AntiCancer Drugs 1997, 8:358-368.

23. Rockwell SC, Kallman RF, Fajardo LF: Characteristics of a serially transplanted mouse mammary tumor and its tissue-cultureadapted derivative. J Natl Cancer Inst 1972, 49:735-749.

24. Otterson GA, Khleif SN, Chen W, Coxon AB, Kaye FJ: CDKN2 gene silencing in lung cancer by DNA hypermethylation and 
kinetics of p I6INK4 protein induction by 5-aza 2 'deoxycytidine. Oncogene 1995, II:I21|-1216.

25. Brenner AJ, Stampfer MR, Aldaz CM: Increased pl6 expression with first senescence arrest in human mammary epithelial cells and extended growth capacity with pl6 inactivation. Oncogene 1998, 17:199-205.

26. Yang AS, Estecio MR, Doshi K, Kondo Y, Tajara EH, Issa JP: A simple method for estimating global DNA methylation using bisulfite PCR of repetitive DNA elements. Nucleic Acids Res 2004, 32:e38.

27. Rockwel SC: Tumor-Cell Survival. In Tumor Models in Cancer Research Edited by: Teicher BA. Totowa (NJ): Humana Press; 2002:6|7-63I.

28. Hsu JC, Peruggia M: Graphical representation of Tukey's multiple comparison method. J Computational Graphical Statistics 1994, 3:|143-16i.

29. Chabot GG, Momparler RL: Antileukemic activity of 5-aza-2'deoxycytidine and cytarabine against intracerebral LI210 murine leukemia. Cancer Treat Rep 1984, 68: | 483- I 487.

30. Momparler RL, Samson J, Momparler LF, Rivard GE: Cell cycle effects and cellular pharmacology of 5-aza-2'-deoxycytidine. Cancer Chemother Pharmacol 1984, 13:191-194.

31. Momparler RL, Momparler LF, Samson J: Comparison of the antileukemic activity of 5-Aza-2'-deoxycytidine, I- $\beta$-D-arabinofuranosyl-cytosine and 5-azacytidine against LI210 leukemia. Leukemia Res 1984, 8:1043-1049.

32. Mayer RJ, Davis RB, Schiffer CA, Berg DT, Powell BL, Schulman P, Omura GA, Moore JO, McIntyre OR, Frei E: Intensive postremission chemotherapy in adults with acute myeloid leukemia. New Engl J Med 1994, 33 I:896-903.

33. Kvinlaug BT, Huntly BJP: Targeting cancer stem cells. Expert Opin Ther Targets 2007, I I:915-927.

34. Tannock IF, Lee CM, Tunggal JK, Cowan DSM, Egorin MJ: Limited penetration of anticancer drugs through tissue: $A$ potential cause of resistance of solid tumors to chemotherapy. Clin Cancer Res 2002, 8:878-884.

35. Chabot GG, Momparler RL: Pharmacokinetics of 5-aza-2'-deoxycytidine in animals and man: relevance to clinical trials. In 5-Aza-2'-deoxycytidine: preclinical and clinical studies Edited by: Dick de Vos, Richard L Momparler. Haarlem, (Netherlands): PCH; 1990:105-II5.

36. Momparler RL, Cote S, Eliopoulos N: Pharmacological approach for optimization of the dose schedule of 5-Aza-2'-deoxycytidine (Decitabine) for the therapy of leukemia. Leukemia 1997, I I(Suppl I): I-6.

37. Skipper HE, Schabel FM Jr, Mellett LB, Montgomery JA, Wilkoff LJ, Lloyd HH, Brockman RW: Implications of biochemical, cytokinetic, pharmacologic, and toxicologic relationships in the design of optimal therapeutic schedules. Cancer Chemother Rep 1970, 54:43I-450.

38. Primeau M, Gagnon J, Momparler RL: Synergistic antineoplastic action of DNA methylation inhibitor 5-aza-2'-deoxycytidine and histone deacetylase inhibitor depsipeptide on human breast carcinoma cells. Intl J Cancer 2003, 103:177-184.

39. Lemaire M, Momparler LF, Farinha NJ, Bernstein M, Momparler RL: Enhancement of Antineoplastic Action of 5-Aza-2'-deoxycytidine by Phenylbutyrate on LI 210 Leukemic Cells. Leukemia \& Lymphoma 2004, 45: I47-I54.

40. Dokmanovic M, Clarke C, Marks PA: Histone deacetylase inhibitors: Overview and perspectives. Mol Cancer Res 2007, 5:981-989.

4I. Piekarz RL, Sackett DL, Bates SE: Histone deacetylase inhibitors and demethylating agents: clinical development of histone deacetylase inhibitors for cancer therapy. Cancer J 2007 13:30-39.

\section{Pre-publication history}

The pre-publication history for this paper can be accessed here:

http://www.biomedcentral.com/1471-2407/8/128/pre pub
Publish with Biomed Central and every scientist can read your work free of charge

"BioMed Central will be the most significant development for disseminating the results of biomedical research in our lifetime. "

Sir Paul Nurse, Cancer Research UK

Your research papers will be:

- available free of charge to the entire biomedical community

- peer reviewed and published immediately upon acceptance

- cited in PubMed and archived on PubMed Central

- yours - you keep the copyright

Submit your manuscript here:

http://www.biomedcentral.com/info/publishing_adv.asp
BioMedcentral 